建築系大学教員の設計教育におけるスケール感の認識と設計課題に関する研究

\title{
A STUDY OF WHAT IS THE CONCEPT OF "SENSE OF SCALE" AND HOW TO TRAIN ITS ABILITY THROUGH THE DESIGN EXERCISES IN THE UNIVERSITIES
}

秋田美 穂*1，戸部 栄一*2

Miho AKITA and Eiichi TOBE

There is reoognition that the recognition of the scale feeling is important respectively in the sense with many sides.

The problem is comparatively done to the scale feeling promotion as effective at early time. The teacher is recognizing that it thinks about the solid, and the composed work, the measurement, and the experienced work are important in the sense of scale promotion.

\section{Keywords : Sense of scale, Design exercise}

スケール感、設計課題

\section{1. 研究目的}

人がどのように空間を癹識しているかということは、哲学や心理 学・地理学など様々な分野で研究されてきた。空閒の認知について は、心理学において人は乳・幼児期には既に自分を取り巻く物体と 環境を把握しているとされている。*1)

また、空閒を学ぼうとする学生にとって空間を把握し仮想空閒を 形として 2 次元及び 3 次元空間に表現する手段は不可久である。で は、空間を特に学ぼうとする学生は既に形成されているという空間 認知に加え、実空間と空想空間を実際にどの過程で認識し利用して いるのか。そもそもスケール感とはどういったもので何を身につけ ることが学生にとって有効なのか。

建築教育における尺度能力形成の研究2)では、スケール感の要素 のひとつであると思われる絶対尺度感は存在せず、尺度能力は記憶 の再認、再生、反復などの訓練により発展する後天的なものとして

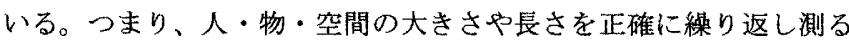
ことで尺度能力を強化させる有効な手段としている。設計教育にお ける準実験的試み*3) では知覚できる空間の領域がスケッチ外の空 間をも把握している学生の評価が高いという傾向から、そのスケー ル感は空間を全体的に想像するる能力が優れていると設計に有効であ るとしている。また、空間想識からみた設計の思考プロセスの考察 *4)では、「視点」は空間の創造、イメージの組み立てといら設計 の操作に解明の糸口を与えるものであり、「視点」の特性や「視点」 の軸のあり方を明らかにすることが、空閒創造や空閒の豊かな構成 の方法につながっていくものであるとしている。さらに図形及び建
築図面に対する建築学科学生の空間認知能力*5) では、図形、図形 問題の閒には正の直線関係が見られる空間認知は図に関する教育と 関わっていることを示唆しているとしている。

他にも高橋鷹志は設計の道具の一つとして識別尺度について語り *6)、またスケール感の概念としては、「スケール感」とは対象の 大きさの把握の正確さや、ものに対する感性だけでなく、体験を成 立させている三要素の複合した体系であるとしている。*7)

過去の既往研究および他分野研究より、空間䜅知やスケールとい った大きな枠では研究されているものの学生のスケール感において のみ大きく注目さてはいない。しかし、スケール感の育成は建築設 計をおこなううえで潜在的に必要不可欠なものであるといえよう。 さまざまな要因を含み、抽象的な存在なだけに、スケール感につい てのみ語られることは少なかったようだ。

本研究では、設計者としては避けて通れないと思われるスケール 感が持つさまざまな多側面を念頭に、各大学の教育担当者がスケー ル感育成の概念をどう捉えているのか、また、各大学ではスクール 感育成を意識した課題の内容をどう構成しているかを明らかにし、 実技課題とスケール感育成との内容を分析することを目的とする。

\section{2. 研究方法}

\section{2-1. 内容と方法}

研究課題は 2 つる。その第 1 はスケール感というものを各大学 の教育担当者がどう捉えているかという問題であり、その第 2 はス ケール感育成と実技・実習課題がどのように対応しているかという
*1 椙山女学園大学生活科学研究科 大学院生

*2 椙山女学園大学生活科学部生活環境デザイン学科 教授・王博
Graduate Student of Sugiyama Jogakuen University

Prof. of Sugiyama Jogakuen University, Dr. Eng. 
問題である。これらのことを知るためには各大学の実技・実習課題 を調べるとともに教育担当者がこれらをどうみているかを知ること が必要である。本研究はこれらの問題への微妙なニュアンスを含め て知るために自由回答方式を軸とするアンケート方式で調查した。 各教員宛に電子メールを送付し、アンケート内容はエクセルファイ ルとして添付した。返信も同様とした。大学のセキュリティー対策 により送信不可能な先には郵送で配布し、返信も同様に郵送で回収 した。

\section{2-2. 調查対象と回収状況}

社団法人日本建築学会発行の 2001 年版「大学 (建築関係学科) 名 簿」より全国の建築系学科を設ける 4 年制大学の計画・設計・意匠 に関する担当講座を担当する教員 150 名に配布した。回収は 31 件であった。尚、31件のうち 14 件が国公立大、1 7 件が私立大 であった。

\section{$2-3$. 調査内容}

（1）スケール感の概念と重要性

スケール感の認識・内容を明らかにするために、ここで、3つの 段階のスケール感の要素として仮に提示し (表一1)、どれが設計能 力向上に向けて重要と思われるかを選択してもらった。しかし、こ れとは別にほかの定義や概念また，スクール感についての別の諗識 があると思われるため、それを自由記述式で併せて回答してもらっ た。

$$
\text { 表-1．スケール感の仮分類 }
$$

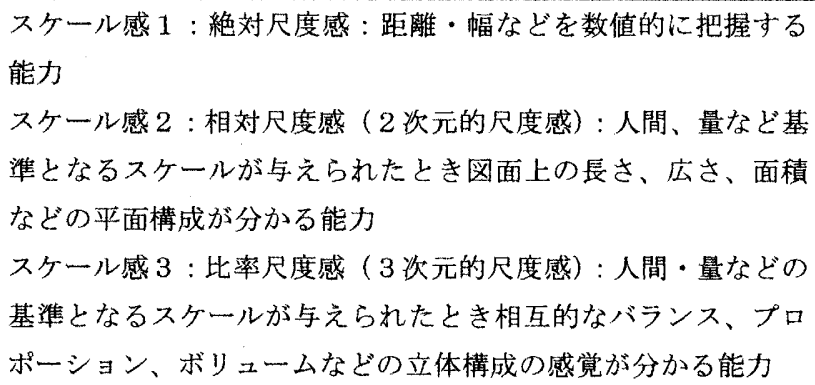

スケール感 2 : 相対尺度感（2 次元的尺度感）：人間、量など基 準となるスケールが与えられたとき図面上の長さ、広さ、面積 などの平面構成が分かる能力

スケール感 $3:$ 比率尺度感（3 次元的尺度感）: 人間・量などの 基準となるスケールが与えられたとき相互的なバランス、プロ ポーション、ボリュームなどの立体構成の感覚が分かる能力

（2）スケール感育成の役割と重要性およびスケール感育成の視点 上記と同様に、設計教育におけるスケール感育成の役割や重要性 についての考えや、どんな視点が重要と思われるが自由記述式で 回答してもらった。

（3）スケール感育成のための教育プログラムの調查

建築設計の教育ではスケール感のみに重点をおいて教授されてい るわけではなく、総合的に効果を得るために行われていることを前提 としたうえで、あえてスケール感育成になるのではないかとして講義 (実習・演習)されている内容と方法について下記のようないくつか の課題項目をあげ(1)それらについて奏施しているか、(2)いつ行なっ ているか、(3)それは主としてスケール感を育成する課題であるか(ス ケール感育成に有効か)、(4) その課題内容を仮説の3 要素の視点で見 るとどの要素育成を行なっているといえるか、を回答してもらった。

課題項目については、建築学会建築教育委員会 1992 年度大会 (北 陸）建築教育部門研究摡談会「設計教育にお污るわが大学の特色ある 試み」1992 年 8 月により報告されたものと、各大学のホームページ上
でスケール感育成をキーワードに行われている内容として検索され たものを参照した。(表一2)

表一2，スケール感育成のための課題の凡例

1. 図面コピー（トレース）2. 模型制作 3. 建筑物などの実測 4. 野帳取り作業 5. 測量実習 6 . 施工奏習 7. 透視図描き 8. 事例の見学 9. 事例の学習 10. 小空閒設計 11. 大空間設計 12. 人間工学学習（モデュール）13. 身体の実測 14.デッサン 15. 原寸図作成 16.スケール比較 17.18.19. その他

\section{3. 分析}

\section{3ー1．スケール感の概念と重要性}

3-1-1．スケール感の要嗉

スケール感の概念と重要性について回答のあった 25 件について 分析する。スケール感の要菜を表一1のように仮に3つに分けた場合、 比率尺度感の重要性の支持が一番多かった。しかし、絶対尺度感や 相対尺度感をあげる人もいた。（表-3）

表-3．スケール感の要素と重要性

\begin{tabular}{|c|c|c|}
\hline 要素 & 回答者数 & 比率 $(\%)$ \\
\hline 1 絶対尺度感 & 6 & 24 \\
\hline 2 相対尺度感 & 4 & 16 \\
\hline 3 比率尺度感 & 15 & 60 \\
\hline & 25 & 100 \\
\hline
\end{tabular}

\section{3-1-2. スケール感の認識}

上記 31 件の返信者のうち 16 件が仮説以外の定義・認識などに ついての意見を様々な方向から 25 寄せている。これは、スケール 感の多様性・多面性を示していると考えられる

この回答はばらばらでフェーズが違うが貴重な示唆があるので、 原文のニュアンスを残しながら分析する。

コメントを読んで気がつくのは、(1)スケール感は絶対的な寸法感 覚(2)スケール感は多次元性をもつ感覚(3)スケール感とは身体化され ることが重要な感覚という 3 タイプの認識があるということである。 もら少し詳細に示すと(1)の絶対的な寸法感覚とは常に立体あるいは 空間 1/1に関するというように絶対音感に近いものとしたもので 5 件あった。(2)のスケール感の多次元性をもつ感覚とは、「人の密度」 「乗降客数」、「頻度」、「速さや動き」、「時間距離」、「視覚できない 状況」などもスケール感に入るというもので 4 件あった。(3)のスケ 一ル感は身体化されることが重要な感覚という指摘は、自分をもの さしとしてはかることい、「建築において、图面を読み感じた空間、 建筑のスケール・ボリュームと害物の見学で直接感じたスケール・ ボリュームなどの誤差を認識すること」といったヒューマンスケー ルに関する意見として11件あった。つまり「獲得」しなければ意味 がないという考え方である。

尚、他には「尺度については比較するものを必要としており、絶対 感覚があるというのは幻想ではないか」とか、「絶対尺度感は個人の 資質に依存する部分が大きいとという教育上で意識してスケール感 を育成するものでないといった意見や、「平面図や模型のスケール感 
は媒介物としての 2 次的なスケール感」や「都市空間におけるスク 一ル感は建築と同様に重要」という方法や状況によってまた別のス ケール感が存在し重要であるといった指摘もあった。

\section{3-1-3. 設計教育におけるスケール感育成の役割と重要性}

では、こうした多面性と媣さを持っスタール感をどのように教育 す心゙きなのか。23の自由記述回答中60のコメントから探った。

スケール感覚は重要であるとあえて述べている意見が8件あった。 しかし、スケール感は時代や文化の理解も必要であり、単にものの 大きさに関する理解力を高めることが目的ではないといった意見が 9 件、個人の資質として自動的に身につくもの、外から教育するも のではないといった意見が 4 件であった。設計においてはスケール 感の重要性についてはふれておらず短期に教育するあるいは教育で 身につくものではないといった指摘である。他は何らかの形でスタ 一ル感育成に関する方法・内容についてコメントをよせている。訓 練によって習得可能という意見が 20 件あり、詳しくは実空間で寸 法感覚を体驗する、よいスケール感をもった空間を奏際に体験する ことが建築を知ることにおいて重要であるなど見学により習得され るものとした意見が 7 件あった。自分で寸法を計測させる、縮尺模 型や図面に表現してスケール対比を学ぶことなど訓練・学習により 習得されるものとした意見が 9 件あった。実寸の世界の寸法知識が 重要であるという実物大で学ぶことにより留得されるものとした意 見が 3 件あった。次にどういう感覚が身につくことがスケール感育 成に有效加という視点については19件あり、詳しくは自分を物差 しと卞ること、肉体的な感觉が伴えば自分の身体がスケール感把握 の強力な道具となるというヒューマンスケール上しての視点が重要 とした意見が 6 件女った。図面の中を歩くことができる、人や物の ある利用の状況と空閒をイメージできることといった空閒を想像で きるとした意見が 8件あった。他に平面・立体の構成に敏感でその空 間をうつくしいプロポーションと評価できること、3 次元のスケー ル感育成が重要、スケール感老理解した上でそれを表現する能力も 必要というコメントもあった。

以上をまとめてみると、各大学の教育担当者はスケール感育成の 方法を図-1のようにみているものと推察される。

\section{3-2. 教育内容とスケール感育成}

(1)。課題実施件数とスケール感育成への有效性

スケール感育成に有効と思われる教育ナ゙ログラムとして表ー 2 の 17 点を挙げ、実施の有無とどんなスケール感育成に寄与寸るかを 回答してもらった。回答は2 5 件である。

全体では 1. 図面コピー (トレース)、2. 模型制作、7. 透視図描き、 8. 事例の見学、9. 事例の学習、10. 小空閒設計、11. 大空閒設計が多 くの大学において行なわれている。このいずれもが高い割合でスケ 一ル感育成に等与していると考えられている。また、2: 模型製作、 3. 建築物などの実測、4. 野帳取り作業、5.測量実習、6. 施工実習、 13. 身体の実測、15. 原寸図作成、16. スケール比較なども実施件数 は少ないものの実施している8割以上が効果的と諮識している。い ずれも、「測ること」にかかわる課題である。（図一2）

（2）実技・実習課題とスケール感育成上の有効性

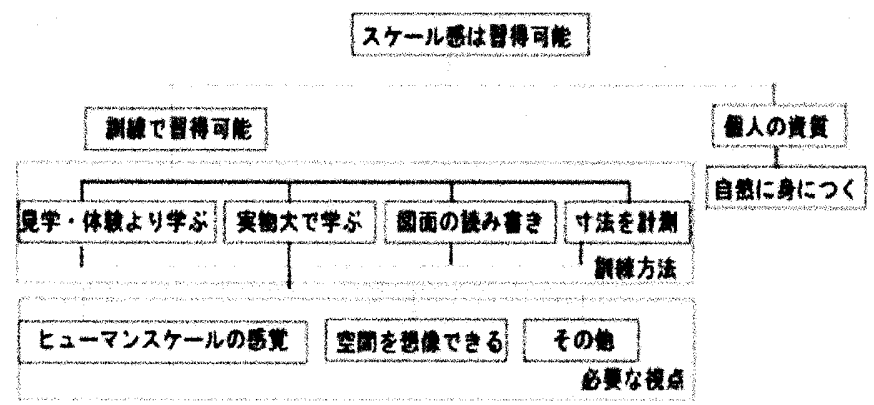

図一 1.スケール感育成方法の概念

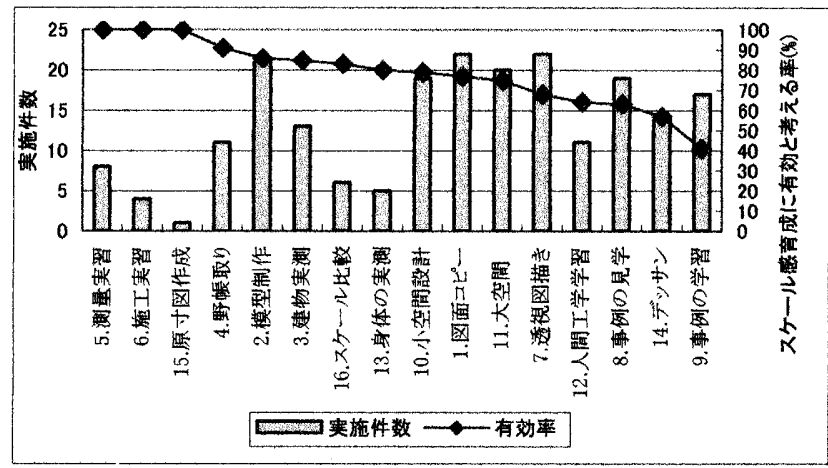

図一2, 高有効率課題順実施課題件数と有効性

16 の課題のうちスケール感育成上有効だとする回答率が $80 \%$ 以上の課題が半数と多く、どの課題も何らかのかたらでスケール感 育成に関わっている。(表-4)

\section{（3）。課題の実施時期とスケール感育成の有効性}

国立、私立のカリキュラム制限や、回答していただいた先生方の 担当課題が中心であるという問題はあるが、実施時期の割合から見 ると各課題の実施時期洨全体的に低学年での実施が多くなっている。 課題の実施時期に時期数を 1 年前期 $1 、 1$ 年後期 $2 、 2$ 年前期 3 と学年半期ごとに設定し、回答していただいた実施時期の割合と描 け、割合の合計数で割ったものを「学年傾向」として算出したもの と、実際の奏施時期の割合の数値をみると、課題には低学年でしか 行われないものと高学年でも行われているものとがあり、大きく下 記の 4 つに分かれる。(表-4)

(1) 主に 2 年前期までに実施されているもの：6. 施工実習、1.図面 コピー、7. 透視図描き、14.デッサン、2. 模型制作、8. 事例の 見学、13. 身体実測

(2) 比較的早い時期に行なわれている傾向はあるものの幅広い学 年にわたって行なわれているもの：10. 小空間設計、12.人間工 学学習、9. 事例の学習

(3) 2 年前期までと 3 年前期からと初期と後期とに分れるもの： 3. 建築実測、4. 野帳取り、15. 原寸図作成、16.スケール比較。

(4) 主に 3 年前期以降に実施されているもの：5. 測量実習、11. 大 空間設計。

これらの分類をスケール感育成に有效とする率と比較してみると、 (3)の初期と後期とに分かれて実施されている課題が有效とする率が 高加た。全体でみると課題の殆どが比較的早い時期に実施されて おり、その多くがスケール感育成を念頭に組まれているようである。 
表一4. 実施時期と学年傾向

\begin{tabular}{|c|c|c|c|c|c|c|c|c|c|c|c|c|c|c|c|c|c|c|}
\hline \multicolumn{2}{|c|}{ 課題番号 } & & 6 & 1 & 7 & 14 & 2 & 8 & 13 & 10 & 12 & 9 & 3 & 4 & 15 & 16 & 5 & 11 \\
\hline \multicolumn{2}{|r|}{ 祼 } & & 施 & 図 & 透 & デ & 模 & 事 & 身 & 小 & 人 & 事 & 建 & 野 & 原 & x & 測 & 大 \\
\hline \multicolumn{2}{|r|}{ 題 } & 時 & I & 面 & 視 & ッ & 型 & 例 & 体 & 空 & 閒 & 例 & 物 & 帳 & 寸 & গ & 量 & 空 \\
\hline \multicolumn{2}{|r|}{ 内 } & 期 & 実 & ב & 図 & サ & 制 & $\infty$ & の & 間 & $I$ & & 実 & 取 & 図 & 1 & 実 & 間 \\
\hline \multirow{2}{*}{\multicolumn{2}{|c|}{ 容 }} & 数 & 習 & ピ & 描 & ン & 作 & 見 & 実 & 設 & 学 & 学 & 測 & $\eta$ & 作 & ル & 習 & 設 \\
\hline & & $\downarrow$ & & 1 & き & & & 学 & 測 & 計 & 学習 & 習 & & & 成 & 比較 & & 計 \\
\hline \multicolumn{2}{|c|}{ 有効率 (\%) } & & 100 & 77 & 68 & 57 & 86 & 63 & 80 & 79 & 64 & 41 & 85 & 91 & 100 & 83 & 100 & 75 \\
\hline \multirow{9}{*}{$\begin{array}{l}\text { 実 } \\
\text { 施 } \\
\text { 時 } \\
\text { 期 } \\
\text { (\%) }\end{array}$} & 1 年前期 & 1 & 67 & 24 & 26 & 27 & 16 & 20 & 20 & 11 & 18 & 8 & 18 & 0 & 0 & 0 & 0 & 0 \\
\hline & 1 年後期 & 2 & 0 & 30 & 16 & 9 & 21 & 7 & 20 & 11 & 0 & 8 & 9 & 25 & 0 & 0 & 0 & 0 \\
\hline & 2 年前期 & 3 & 33 & 45 & 47 & 56 & 47. & 53 & 40 & 47 & 45 & 50 & 18 & 25 & 50 & 40 & 25 & 16 \\
\hline & 2 年後期 & 4 & 0 & 0 & 5 & 0 & 11 & 7 & 0 & 16 & 18 & 17 & 0 & 0 & 0 & 0 & 0 & 5 \\
\hline & 3 年前期 & 5 & 0 & 0 & 0 & 0 & 0 & 7 & 0 & 11 & 0 & 0 & 9 & 0 & 0 & 20 & 50 & 42 \\
\hline & 3 年後期 & 6 & 0 & 0 & 5 & 9 & 5 & 7 & 20 & 5 & 18 & 17 & 18 & 25 & 50 & 20 & 25 & 32 \\
\hline & 4年前期 & 7 & 0 & 0 & 0 & 0 & 0 & 0 & 0 & 0 & 0 & 0 & 27 & 25 & 0 & 20 & 0 & 5 \\
\hline & 4年後期 & 8 & 0 & 0 & 0 & 0 & 0 & 0 & 0 & 0 & 0 & 0 & 0 & 0 & 0 & 0 & 0 & 0 \\
\hline & 合計 $(\%)$ & & 100 & 99 & 100 & 100 & 100 & 100 & 100 & 100 & 100 & 100 & 100 & 100 & 100 & 100 & 100 & 100 \\
\hline \multicolumn{2}{|r|}{ 実施件数 } & & 3 & 20 & 19 & 11 & 19 & 15 & 5 & 19 & 11 & 12 & 11 & 8 & 2 & 5 & 4 & 19 \\
\hline \multicolumn{2}{|r|}{ 学年傾向 } & & 1.66 & 2. 19 & 2. 49 & 2.64 & 2.73 & 2.98 & 3.00 & 3.23 & 3.33 & 3.44 & 4. 32 & 4.50 & 4. 50 & 4.80 & 4.75 & 5.05 \\
\hline \multicolumn{2}{|c|}{ 時期数 $1+2+3$} & & 100 & 99 & 89 & 91 & 84 & 80 & 80 & 69 & 63 & 66 & 45 & 50 & 50 & 40 & 25 & 16 \\
\hline \multicolumn{2}{|c|}{ 時期数 $5+6+7+8$} & & 0 & 0 & 5 & 9 & 5 & 14 & 20 & 16 & 18 & 17 & 54 & 50 & 50 & 60 & 76 & 79 \\
\hline
\end{tabular}

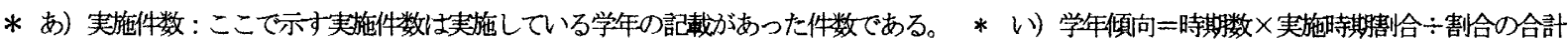

4. まとめ

以上の調查の分析から、学生の設計能力向上とスケール感育成に 関して以下のようなことが結論付けられる。

1. 短期に身につくものでないと考える教員もいるものの多くの教 員がスケール感育成の重要性を認識しており、建築教育の中で㕕成 できると考えている。

2.スケール感そのものの認識としては(1)スケール感は絶対的な寸 法感覚(2)スケール感は多次元性をもつ感覚(3)スタール感とは身体化 されることが重要な感覚というような見方があった。

3.その教育方法としては、見学・体験より学ぶ、実物大で学ぶ、 図面の読み書きから学ぶ、寸法を計測して学ぶという訓練により習 得可能として行なわれている。その際、ヒューマンスタールの感覚 や、空間を想像できる感覚などを意識しながら教育をすることが有 効とみているように推察される。

4.さまざまな課題はスケール感育成に関係していて、その実施時 期仗早い時期に行なわれるものと、遅い時期に行なわれるものとそ の双方におこなわれているものに分かれ全体を通して比較的早い時 期に実施されている傾向であった。

5. 害技課題のうち採用件数が多くスケール感育成に有効と考えら れている課題に、2. 模型製作、10. 小空閒設計、1. 図面コピーがあり、 実施件数は少ないがスケール感育成に有効と考えられる課題に、 5. 測量実習、6. 施工実習、15. 原寸図作成があった。前者は立体を考え
構成する作業であり、後者は測り体験する作業である。これらを教 員はスケール感育成に重要であると認識していると推察される。

謝辞 お忙しい中、スケール感育成に関する貴重なご意見をいただ きました先生方に深く感謝申し上げます。

\section{参考文献}

1) ナイジェル・F・ラファエル：空間認知研究ハンドブック 二瓶社

2）稲葉武司：建築教育に抬ける尺度能力形成の研究、共立女子大学研究紀 要, 2000

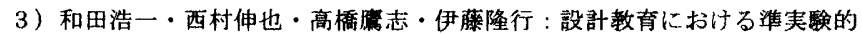
試み一「場面」設定が設計に与える影響一, 日本建筑学会計画系論文集、第 516 号, pp. . 145-151, 1999. 2

4）西村伸也・高橋鷹志・服部久雄・石田滋之・藤井昌幸：空間認識加らみ た設計の思考プロセスの考察一「視点」による学生課題設計の分析一, 日本建 勧学会計画系論文集、第 455 号、pp. . 87-96, 1994. 1

5) 知花弘吉・阿倍浩和・吉田勝行：図形及び建築図面に対する建築学科学 生の空間認知能力、日本建築学会 第 4 回建築教育シンポジウム 建築教育 の行方をめぐって、pp. . 43-54, 2004

6) 高橋鷹志：設計方法四 設計プロセス/道具の提案 日本建筑学会 建策 計画委員会 pp. 39-44.1974

7）高橋鷹志：建筑と社会 特集スケール感, 日本建筑協会 pp. 35-61.1990 